\title{
Presidential Keynote
}

\author{
ANDREw Sims, President, The Royal College of Psychiatrists
}

Three years is a long time in the life of a President, rather longer than the gestation of an elephant, and about the time that my vines took to start bearing fruit! As I write this in February we are in the middle of the rugby season; Union in the four nations served by the College, and League, also here in Yorkshire. I see the role of the President rather like a good fly-half - a strategic and accurate pass will enable somebody else to score; when in trouble, kick for touch and gain as much territory as possible: A flyhalf rarely scores tries himself? The College and its Officers try to improve the ground for the practice of psychiatry, but it is Members and Fellows locally who can capitalise on this and improve the quality of care for their patients.

Having to write this is a salutary exercise and before doing so I read what I set as my goals in 1990. They were as follows:

(a) pursue with energy greater resources for mental health

(b) aim to achieve good psychiatric services in the plans for the National Health Service

(c) try to strengthen individual psychiatrists in their own practices

(d) encourage our members overseas as they raise standards, through the Overseas Desk of the College

(e) continue pressing for increased manpower in psychiatry.

I still stand by these. I wrote that I saw the President "as having a crucial role in representing the needs of psychiatric patients and the specialty to Government and the rest of the medical profession". I have tried hard to do that; and it remains necessary.

I am glad to be unable to remember, now, which actions were mine, and which made others. I have been fortunate in working with a superb team with the utmost support from other officers of the College; if we have achieved anything that is why.

We are also most fortunate in the College to have an excellent, friendly, dedicated, intelligent and cooperative staff. This is true for all the departments in the College, both those I have seen regularly as President (and before that as Dean), and also those who are not so conspicuous but nevertheless absolutely essential for its smooth running.

The work of the College is constantly expanding and our resources are finite, always hard-stretched.
So far our Treasurer and his staff have kept us fully functioning, but I would expect it to become increasingly difficult to find the balance between what we want to do and what is financially possible. I feel the country obtains a bargain in our monitoring clinical standards and supervising postgraduate education.

During the last couple of years specialist registration has been introduced by the General Medical Council; we have tried to implement this fairly and conscientiously for psychiatry. Substantial expansion in College publications is mostly directed at helping psychiatrists to do their job better. The British Journal of Psychiatry remains one of the world's preeminent psychiatric journals. The Research Unit of the College produces much invaluable work on the assessment of needs in psychiatry, on clinical audit and on the standards and targets that should be set; it has become a force nationally. The library of the College continues to provide invaluable information both outside and inside the College (indispensable is the provision of instant facts and figures for the President!). It is also an increasingly used archival library for psychiatric institutional history. The first College Manpower Census was carried out in September 1992 for the United Kingdom and Ireland; when analysed the results will be of great practical use.

An innovation I made was the President's Essay Prize, now in its third year. Topics have always been set to give me ideas and information that I needed as President. I also consult the experts, but the essayists have often been able to provide a fresh approach to a complex subject.

The College has made great effort to improve mental health services, and has emphasised the role of the individual consultant. We decided to produce a blueprint rather than just respond to Government documents, and so Council, in January 1992, set up a working party that resulted in the publication of the Report, Mental Health of the Nation, in August 1992. This dealt with organisation of the individual consultant service, requirements for in-patient beds, and needs for consultant manpower. It was published within three weeks of the government strategic document, Health of the Nation, which had included mental illness as one of five key areas. Mental Health of the Nation therefore became an immediate response by the College to Health of the Nation. It 
is very much hoped that our Report will benefit consultant psychiatrists in their negotiations with management for resources and better organisation in their own local areas.

Also in January 1992 the Confidential Enquiry into Homicides and Suicides by Mentally Ill People was established in the College under the direction of Dr Boyd, following an initiative from the then Minister of Health, and financed by the Department of Health. By early 1993 the Confidential Enquiry is now functioning, and it is hoped that it will aid clinical audit for the United Kingdom, and will produce information to improve our practice.

Following the highly publicised tragedy of a patient suffering from schizophrenia climbing into the lion's den at London Zoo on New Year's Eve 1992, a very public debate ensued between the College, the Secretary of State for Health, the Department of Health and other interested parties on the need for a community order for a small number of severely mentally ill people living outside hospital. A report was accepted by Council in January 1993 proposing a "Community Supervision Order". This is currently being considered by Government and other relevant bodies.

College educational activities have increased over the last three years. The Examination has seen a period of consolidation with increased numbers of candidates, and postgraduate education remains a strength of our College. The major innovation has been in the field of continuing medical education (CME) for consultants, and it is hoped that this programme will substantially improve our practice. Deficiencies in the delivery of electro-convulsive therapy (ECT) by psychiatrists was revealed in work carried out through the Research Unit, and CME courses are helping consultants responsible for ECT in district hospitals get up to date. The College Overseas Desk has continued active with regional meetings, work towards mutual recognition of training, and the initiation of the Lundbeck Teaching Fellowship programme whereby psychiatrists from the United Kingdom have taught in countries as far separated as Bulgaria and Chile.

Public Education has been taken seriously. Good relationships have been established with the media, with a panel of experts available among the College membership, regular press conferences and releases on significant occasions, and training of officers in how to deal with the media. The Defeat Depression Campaign was launched in January 1992, and for its first year was occupied with the education of general practitioners in the identification and treatment of depression. Several million leaflets on psychiatric topics such as Bereavement, Surviving, Adolescence, and Anorexia \& Bulimia have been distributed to the general public through general practices and have been well received. We particularly welcome collaborating with other medical Royal Colleges and I consider it an honour to have served as Vice Chairman of the Conference of Medical Royal Colleges.

Where do we go from here? I do not know - but it is quite clear that the many changes taking place in the National Health Service, in the interface with social services, with the hoped for implementation and funding of the recommendations of the Reed Committee, will undoubtedly mean a great deal of discussion with Government and others. There is a continuing need for consultants more recently established in their posts to be affirmed in carrying out their clinical work, leading a multidisciplinary team and providing a high quality of service for an identified and limited number of individual patients. There needs to be an emphasis on good after-care following discharge from hospital and also the provision of a range of treatments, including psychological and social interventions. Recruitment to psychiatry remains excellent and, so, I cannot be other than optimistic about the future of our discipline in Britain. After three years of such intense activity $I$ am personally involved in the health and future prospects of the College; my successor and her team of officers will serve the College well and I wish them every success. 